\title{
Att lära av det lokala och experimentera. Resilienstänkande i brottsförebyggande arbete
}

\author{
Vanja Lozic
}

SAMMANDRAG: Samtida samhällsutmaningar beskrivs alltmer som komplexa och oförutsägbara samtidigt som risker för människors och samhällets trygghet och säkerhet anses ha ökat under det senaste decenniet. Problembilderna har lett till ett skifte i synen på brottsprevention där resiliens som begrepp och styrsystem fått stort genomslag inom brottsförebyggande arbete. Mot bakgrund av resilienstänkandets ökade inflytande analyserar Vanja Lozic hur representanter för blåljusmyndigheter, kommun och frivilligorganisationer framställer och legitimerar resiliensinspirerat förebyggande trygghets- och säkerhetsarbete. Artikeln visar att det finns en kritik mot tidigare organisering av förebyggande arbete som anklagas för stuprörstänkande, kortsiktighet och bristande förankring i lokalsamhället. Intervjuerna och fältobservationerna synliggör att man i stället efterfrågar helhetstänkande, anpassning till det lokala, samverkan, experimentering och transformativt och relationellt lärande. Det nya arbetssättet med informellt och nätverksbaserat samarbete liksom ett närmande till och inkludering av lokalbefolkningen ses av de medverkande som en demokratisering av brottspreventionen.

NYCKELORD: resiliens; brottsprevention; samverkan; lärande; lokalsamhälle; utsatta områden.

PUBLICERINGSHISTORIK: Originalpublicering.

VANJA LOZIC är universitetslektor i pedagogik vid Malmö universitet.

E-POSTADRESS: vanja.lozic@mau.se

FÖRSLAG PÅ KÄLLANGIVELSE:

Lozic, Vanja (20I8) "Att lära av det lokala och experimentera. Resilienstänkande i brottsförebyggande arbete", i Platskamp, specialnummer av Arkiv. Tidskrift för sambällsanalys, $\mathrm{nr}$ 9, s. I29-I57.

DOI: https://doi.org/IO.I3068/2000-6217.9.5

(C) Vanja Lozic/Arkiv förlag \& tidskrift 2018 (publicerad 28 maj 20ı8)

Artikeln distribueras enligt en upphovsrättslicens från Creative Commons:

Erkännande-Ickekommersiell-IngaBearbetningar 3.o Unported, som medger fri ickekommersiell användning och spridning i oförändrat skick så länge källan anges. 
Arkiv. Tidskrift för samhällsanalys är en sakkunniggranskad vetenskaplig tidskrift för samhällsvetenskap och historia. Samtliga artiklar publiceras fritt tillgängliga på:

$$
\text { www.tidskriftenarkiv.se }
$$

Beständig länk, DOI: https://doi.org/IO.I3068/2000-62I7

Den här artikeln finns tillgänglig i följande format:

PDF: via beständig länk, DOI: https://doi.org/IO.I3068/2000-6217.9.5

TRYCK: ingår i bokutgåva av numret, ISBN: 978 9I 79243159

Grafisk utformning och sidnumrering är identisk i pdf och tryck.

Samtliga artiklar i nr 9 (2018), Platskamp, nås via beständig länk, DOI: https://doi.org/I0.I3068/2000-6217.9

Redaktion för nUmret: Magnus Dahlstedt, Lisa Kings \& Nazem Tahvilzadeh

Arkiv. Tidskrift för sambällsanalys

ISSN: 2000-62I7 (för elektronisk resurs)

ISSN: 2000-6225 (för tryckta nummer)

ges ut av

Stiftelsen Arkiv för främjande och spridning av samhällsvetenskaplig och historisk forskning

\author{
genom \\ Arkiv förlag \& tidskrift \\ Box 1559 \\ SE-22I OI Lund \\ BESÖK: L Gråbrödersg 3 c, ipg \\ TEL: 046-I3 3920
}

ARKIV FÖRLAG: arkiv@arkiv.nu·www.arkiv.nu

TIDSKRIFTEN ARKIV: red@tidskriftenarkiv.se.www.tidskriftenarkiv.se

ANSVARIg UTGIVARE \& CHEFREDAKTÖR: Sven Hort

AdMinistrativ Redaktör: David Lindberg

Redaktörer: Paavo Bergman, Per Dannefjord, Lisa Kings,

Zhanna Kravchenko, Anna-Maria Sarstrand Marekovic 


\title{
Att lära av det lokala och experimentera. Resilienstänkande i brottsförebyggande arbete
}

\author{
VANJA LOZIC
}

Sedan millennieskiftet har olika former av sociala rörelser, upplopp och uppror i europeiska städer, tillsammans med religiös och annan form av våldsbejakande extremism och radikalisering, väckt en livlig debatt om ungdomsproblem, trygghet och säkerhet, riskfaktorer och de mångkulturella samhällenas framtid (Mayer 20I6). Dessa och andra problembilder, samt föreställningar om problemens och riskernas eskalering, har lett till att över femtio svenska bostadsområden nyligen har klassificerats som "utsatta områden" (Polisen 2017, 2015). Samtidigt har trygghetsoch säkerhetsfrågor fått en framskjuten betydelse för vår förståelse av samtiden, något som blivit särskilt framträdande i svenska politiska diskurser och mediedebatter (Andersson \& Nilsson 2017; Edvall Malm 2012; Söderberg 2016; Andersson 2017).

Fler poliser, höjda straff och ökad övervakning tillsammans med implementering av generell brottsprevention, inte minst inom ramen för lokala samverkansprocesser, är de lösningar som lyfts fram vad gäller problemen i de utsatta områdena. Genom ökad involvering av lokalsamhället och frivilligorganisationer - både i Sverige och internationellt - har ansvaret för brottsförebyggande arbete successivt förskjutits från staten till flera olika aktörer (Andersson \& Nilsson 20I7; Andersson 20I7; O'Malley 20I3; Chandler 20I4). Samverkan mellan olika parter (till exempel statliga och kommunala aktörer, medborgare, näringslivet och frivilligorganisationer) har också inneburit nya utmaningar. Samverkan 
har till exempel krävt omvärdering av sätt att organisera arbetet, förstå sitt professionella uppdrag och sin yrkesidentitet, arbetskultur och medborgarroll (Söderberg 2016; Andersson 20I7).

Välfärdspolitiska problematiseringar som lägger tonvikt på samverkan, medborgardialog, brottsprevention, säkerhetisering och komplexiteten i dessa frågor, har både internationellt och i Sverige alltmer utgått från resiliensinspirerat tänkande som en central förståelsehorisont och lösning (Gressgård \& Lozic kommande; Corry 2014; MSB 2013, 20I6a, 20I6b). Resilienstänkande (engelska resilience) baseras på antagandet att samhället har blivit alltmer komplext, vilket innebär att man behöver gå ifrån centralstyrd säkerhetspolitik och kortsiktiga trygghetsskapande åtgärder (Chandler 20I4). Ett eftersträvansvärt mål anses vara inkludering av olika organisationer och aktörer (privata aktörer, civilsamhället, myndigheter, medborgare och så vidare) i underifrånbaserad brottsprevention. Poängen som lyfts fram är att riskernas och problemens komplexitet och oförutsägbarhet kräver innovativa lösningar, ständig anpassning till och kontinuerligt lärande utifrån lokala villkor samt experimentering i det lokala och aktivering av medborgarna. Trots resilienstänkandets stora genomslagskraft under det senaste decenniet (se t.ex. Bergström m.fl. 2015) har lokala brottsförebyggande insatser och problematiseringar baserat på resilienstänkande blivit relativt outforskade i Sverige.

Mot bakgrund av resilienstänkandets ökade betydelse är mitt övergripande syfte i den här artikeln att synliggöra hur olika organisationsrepresentanter (för blåljusmyndigheter, kommuner och frivilligorganisationer), involverade i en samverkansprocess, framställer och legitimerar resiliensinspirerat förebyggande trygghets- och säkerhetsarbete. Studien av denna samverkan i ett så kallat särskilt utsatt område i en svensk storstad, ger en fördjupad förståelse för förändringar i samtida brottsförebyggande arbete i allmänhet och resilienstänkandets genomslagskraft $\mathrm{i}$ en svensk kontext i synnerhet. Härigenom diskuterar jag också förändrade relationer mellan involverade aktörer och konstitueringen av nya medborgarideal och yrkesidentiteter. Utifrån denna syftesförklaring har följande huvudfrågor utkristalliserats: På vilka sätt har resilienstänkande blivit en viktig förståelsehorisont i brottsprevention? Hur beskrivs 
orsakerna till ökade behov av samverkan och vad kännetecknar eftersträvansvärda resiliensinspirerade arbetsformer i det studerade särskilt utsatta området? Vilka konsekvenser har nya former av trygghets- och säkerhetsarbete för relationerna mellan partnerorganisationer och mellan organisationer och lokalsamhället?

Artikelns övergripande slutsats är att samverkansdeltagarna riktar en skarp kritik mot tidigare organisering av trygghets- och säkerhetsarbete, som anklagas för ineffektivitet, stuprörstänkande, kortsiktighet, bristande förankring i lokalsamhället och otillräcklig anpassning till det specifika urbana rummet. De anser att komplexa problem kräver helhetstänkande, anpassning och samverkan mellan olika aktörer situerade i det lokala sammanhanget, kontinuerlig experimentering, kontextuellt, transformativt och relationellt lärande samt konsoliderande och legitimerande kommunikationsstrategier. Genom att vara inbäddad i resilienstänkande representerar den studerade samverkansprocessen en förskjutning av synen på maktrelationer och styrning - från en tydlig ansvarsfördelning och centralt fastställda organisationsramar till ett mer informellt och nätverksbaserat beslutsfattande, reflexiv styrning, affektiva arbetssätt och en förskjutning av ansvaret till individer, något som tolkats som en demokratisering av brottspreventionen.

\section{Från centralstyrd välfärdspolitik till nyliberal decentralisering}

Samtida samhällsutmaningar som upplopp, kriminalitet, radikalisering och andra problem i europeiska storstäder har företrädesvis relaterats till socioekonomiskt utsatta storstadsområden (Wacquant 2008; Thörn m.fl. 20I6). I rampljuset för den svenska politiska och mediala debatten står stigmatiserade storstadsområden - byggda som en del av det så kallade miljonprogrammet, ett omfattande centralstyrt bostadsbyggande mellan 1965 och 1975 - liksom ungdomar och unga vuxna bosatta där (de los Reyes m.fl. 20I4; Ranstorp 20I5; Schierup m.fl. 20I4; Hallin m.fl. 20Io). Redan från början beskrevs dessa områden, "miljonprogrammet", "invandrartäta områden", "utanförskapsområden" och "utsatta områden", som problematiska (Ristilammi 1999). Men medan I970-talets 
problemdiskurser företrädesvis handlade om de boendes arbetarklassbakgrund och låga utbildningsnivå har problemdiskussionerna sedan I980-talet rört frågor om migration, kulturskillnader, rasifiering, etnicitet samt segregation (Molina 1997; Arnstberg 2000; Lozic 2016). Fem decennier av dessa urbana stadsområdens historia genomsyras också av stora satsningar på brottsförebyggande arbete, det vill säga åtgärder som syftar till att "motverka en negativ utveckling, men också att främja en positiv" (Sahlin 2000, s. 23).

De omfattande bostadsbyggnadsprojekten och en brottsförebyggande politik var en del av framväxten av Sverige som välfärdsstat. Under de tio åren då dessa bostadsområden byggdes, med målet att ge alla medborgare moderna och prismässigt överkomliga bostäder och således lösa dåtidens bostadsproblem, skedde också en tydlig förskjutning i synen på brottslighet, som alltmer började betraktas som ett strukturellt snarare än ett individuellt och patologiskt problem (Andersson \& Nilsson 20I7). Utgångspunkten var att sociala och ekonomiska förutsättningar och problem leder till att vissa individer begår brott och under denna period utvecklades en strävan från samhällets sida att undanröja strukturella hinder. Således skulle så kallad välfärdskriminalpolitik, baserad på social ingenjörskonst, välfärdspolitiska åtgärder (till exempel jämlikhetsarbete) och statligt producerad expertkunskap (framför allt framtagen av Brottsförebyggande rådet som inrättades 1974) bidra med att komma till rätta med problemens grundorsaker (till exempel arbetslöshet, undermåligt boende och brister i närmiljön) (Andersson \& Nilsson 20I7; Söderberg 20I6).

Kring 1980 började dock den välfärdspolitiska ideologin, inspirerad av socialdemokratisk reformistisk tradition, att ifrågasättas. Kritikerna menade att åtgärderna mot brottslighet hade blivit alltför ideologiserade och man efterfrågade ett mer vetenskapligt, praktiknära och experimentellt förhållningssätt till brottsbekämpning och brottsprevention. Utifrån vetenskapliga argument, neutralitet och forskning som dominerande diskurser förkastade man vad man ansåg var "'otydliga' faktorer som arbetslöshet, social uteslutning och socialt handikapp", i stället lades fokus på "bristande kontroll över platser och/eller personer" som ansågs utgöra en risk för och ett hot mot samhällsordningen (Andersson \& Nilsson 20I7, s. I45). Ytterligare en kritik som riktades mot strukturana- 
lys och välfärdspolitik var att de ansågs representera "en form av statlig maktutövning över hemmet, barnuppfostran och livsstilar" och en politik som "skapar inlärd hjälplöshet och 'bidragsberoende', underminerar familjens roll och individens eget ansvar (och kostar för mycket)" (Sahlin 2000, s. 93). Den så kallade kontrollmodellen som växte fram i spåren av kritiken av strukturella orsaksförklaringar handlade således om att försöka "reglera beteendet hos enskilda individer, grupper eller hela befolkningen" och att kartlägga riskfaktorer och sedan försöka kontrollera dem (Sahlin 2000, s. 99).

Motgångarna för en välfärdspolitisk brottsbekämpning, de strukturella orsaksförklaringarnas tillbakagång och den efterföljande implementeringen av riskprevention och kontrollpolitik under 1980- och 1990-talet har både i Sverige och internationellt tillskrivits den nyliberala vändningen (Andersson \& Nilsson 2017; O’Malley \& Hutchinson 2007). Förändringen innefattade bland annat avregleringar och förskjutning av ansvaret till försäkringsbolag och andra privata aktörer. Symptomatiskt var införandet av ekonomiskt ansvar, effektivitet och kostnads-nyttoanalys som centrala mål. Därutöver har medborgare fått ta ett allt större ansvar för åtgärder mot brott och andra samhällsproblem. Ett centralt argument i motiveringen av den politiska omvandlingen har varit att samhället blir mer demokratiskt om besluten flyttas närmare medborgarna och lokalsamhället samtidigt som arbetet blir mer effektivt och anpassat till lokala behov när man går ifrån centralstyrd myndighetsutövning.

Fram till mitten av 2000-talet fanns det en kritik mot denna omsvängning grundad på strukturella orsaksförklaringsmodeller, menar Robert Andersson och Roddy Nilsson (20I7). Enligt dem tystnade denna kritik under 2000- och 20I0-talet. I spåren av dessa förändringar har det skett en successiv förskjutning i synen på brottsprevention så att makt-, klass- eller socioekonomiska perspektiv har fătt en marginaliserad plats $\mathrm{i}$ de dominerande problembeskrivningarna. Dessutom har trygghets- och säkerhetsfrågor under det senaste decenniet fått en betydelsebärande plats på den politiska dagordningen och i samhällsdebatten. Andersson och Nilsson (20I7) konstaterar att det i dag råder en konsensus om att brottsprevention ska genomsyra alla sfärer av samhället och att i den samtida 
styrningsrationaliteten spelar partnerskap och samverkan mellan kommunala och statliga organisationer, näringslivet, frivilligorganisationer och medborgare en central roll för brottsprevention. Med "styrningsrationalitet" menas här viljan att definiera och förstå ett problem samt utforma lösningar i syfte att förändra någons beteende eller en miljö i en önskvärd riktning (Rose m.fl. 2006; Rose 1999). Organisationer och institutioner såsom skola, familj, sjukvård, fastighetsägare, stadsplanerare, näringslivet, kulturföreningar och vaktbolag har genom olika samverkansinitiativ fått en mer framskjuten roll i trygghets- och säkerhetsarbete samt i utvecklingen av "problematiserade" områden och dess medborgare - spörsmål som staten tidigare hade ensamrätt på (jfr Andersson 20I7; Dahlstedt \& Hertzberg 20II; Sullivan \& Skelcher 2002).

Det bör samtidigt poängteras att samverkan i sig på intet sätt är ett nytt fenomen i svensk politisk vokabulär och styrning. Tvärtom så har samverkan varit en integrerad del av svensk välfärdspolitik under stora delar av efterkrigstiden (Sahlin 2000; Hertting 2003; Ekberg 20IO). Fram till 2000-talet var sådana samarbeten kortvariga och tidsbegränsade projektbaserade insatser, strukturerade inom ramen för enskilda partnerorganisationers och professioners befintliga mål, yrkesbeskrivningar och mandat (Hertting 2003; Söderberg 2016; Sahlin 2000). Till skillnad från processer präglade av en mer formaliserad ansvarsfördelning, med definierade arbetsuppgifter, centralutformade och kontraktsenliga föreskrifter och nationell finansiering - som tidigare har dominerat i Sverige - baseras samtida samverkansprocesser i allt större utsträckning på inkludering av det lokala samhället, dialog, platta nätverksstrukturer, gemensamma framtidsvisioner och mål, medborgarnas aktiva deltagande, relationsbyggande och underifrånperspektiv (Edvall Malm 20I2; BRÅ 20I6; Andersson 20I7; Gressgård 20I6; Lozic 2016). Enligt David Chandler (2014) och Olaf Corry (2014) går det att tala om en internationell framväxt av resiliensinspirerade former av samverkansprocesser, som kännetecknas av institutionellt och professionellt gränsöverskridande, hybriditet och affektivt relationsbyggande och synen att ekonomisk styrning och kontroll bör ersättas med ett mer holistiskt tankesystem. Därför vill jag i det följande kortfattat beskriva vad som kännetecknar resiliens som styrningsrationalitet och policypraktik. 


\section{Resiliens: styrningsrationalitet i en komplex värld}

I säkerhetspolitiska, miljöpolitiska och andra sammanhang används resiliens - som kan definieras som motståndskraft mot risker, anpassningsförmåga och kraft att återhämta sig efter en krissituation - för att I) förstå och förklara de utmaningar som samtida urbana rum står inför och 2) utforma dagens säkerhetspolitik (Chandler 20I4; Coaffee 20IO, 20I3; Vale 20I4). Ett ofta förekommande skäl för implementering av resiliens är att i ett komplext samhälle där framtiden inte kan förutsägas, är det däremot möjligt att förbereda sig för att bli mer motståndskraftig, hantera oförutsedda händelser samt minska annalkande risker. Resiliens utgår således från kritiken av kontrollerbarhetsdiskurser, centralstyrning, organisatorisk gränsdragning och stuprörstänkande (Chandler 20I4). Samtidigt påpekas vikten av att konstituera subjekt (hos både de professionella och medborgarna) som kännetecknas av förmågan att anpassa och utveckla sig själva och samhället i stort, skapa nätverksbaserade, flexibla, affektiva och innovativa strukturer, arbetssätt och sociala band (O’Malley 2013). Inom resiliens framhävs innovationstänkande, permanent anpassningsbarhet, livslångt lärande, prövande, reflexivitet och flexibilitet som viktiga kompetenser (O’Malley 2013; Walker \& Cooper 20II). Därutöver efterfrågas samarbete med och förståelse av lokalsamhället. Resiliens vilar på synen att närhet till det lokala möjliggör genomgående analys och förståelse av och anpassning och återkoppling till nya och ständigt föränderliga samhällsutmaningar i sårbara urbana rum och lokalsamhällen.

Å ena sidan anses de boende i lokalsamhället vara utsatta, en riskfaktor och ett problem i sig, å andra sidan uppfattas de som bärare av viktiga kunskaper om området och en källa till förändring av både det lokala, sig själva och organisationer. Genom att betrakta människor som en tillgång vilar resiliens på synen att demokrati och styrning handlar om att stärka och ge makten till lokalsamhället och yrkesutövarna i det lokala (Chandler 20I4). Eftersom resiliens har inneburit ett tilltagande fokus på medborgardialog och kunskapsutbyte anses resiliens av förespråkarna även vara en demokratiserande, lyssnande, reflexiv, holistisk och långsiktig styrningsrationalitet och en policypraktik som tar hänsyn till och utgår från medborgarnas önskningar, behov och erfarenheter. 
Sammantaget förkastas gränsdragningar mellan yrkesgrupper och roller, linjestyrning, reduktionism och revirtänkande och i stället understryks betydelsen av mångfald och lärande (Coaffee \& Clarke 2015; Chandler 20I4). Det framhålls att eftersom helheten är större än summan av delarna så kan man varken organisera samhällsinstitutioner och tackla problem genom institutionell differentiering av arbetsuppgifter och professioner eller centralt, i förväg och i isolering från det lokala planera lämpliga åtgärder. Adaptiv, lyssnande, mångfasetterad, lärande, affektiv, långsiktig, integrativ och holistisk organisering utifrån de behov och förutsättningar som råder i det lokala är därmed viktiga motton i resiliens.

\section{Metodologiska överväganden}

Med målet att synliggöra resilienstänkandets genomslagskraft i lokal brottsprevention i ett svenskt särskilt utsatt område analyserar jag fältobservationer från nätverksmöten och samverkansdialoger insamlade under perioden 20I4-20I8 inom ramen för en samverkansprocess (nedan kallad "Närområdets gemensamma styrka”, NGS). Dessutom har jag i syfte att få en bild av de grundidéer som samverkansprocessen vilar på intervjuat två organisationsrepresentanter, en verksam inom en blåljusmyndighet och en i en frivilligorganisation (nedan kallade "trygghetssamordnaren Ellis" respektive "temasamordnaren Lo"). Intervjupersonerna har valts på grund av deras passionerade engagemang i den studerade samverkan och deras roll som initiativtagare, samordnare och/ eller inspiratörer. Intervjuerna spände över en mängd olika teman, men kretsade framför allt kring deras arbete med ungdomar och deras sätt att förstå, beskriva och motivera samverkan. Samtliga uppgifter om individer, platser och händelser har anonymiserats och samtliga inblandade personer har fått information om forskningsprojektets syfte. Intervjuer och observationsanteckningarna från över trettio timmars möten och aktiviteter har kompletterats med kommunikationsmaterial och dokument som distribuerats bland deltagarna av samverkan och utåt mot intresserad allmänhet. Den rumsliga kontexten inom vilken samverkansprocessen har ägt rum är ett särskilt utsatt område i en svensk storstad. Enligt Polisen (20I7), BRÅ (20I7) och Rädda Barnen (20I5) känneteck-

I. NGS är ett fingerat namn. 
nas området (nedan kallat "Närområdet") av oroligheter, otrygghet, hög brottslighet, socioekonomisk och bostadsmässig segregation, barnfattigdom, arbetslöshet, misstro mot rättsväsendet och ordningsmakten, dåliga skolresultat och så vidare.

I analysen av empirin fokuserar jag på problematiseringar av Närområdet och de lösningar som förespråkas. Carol Bacchi (2010, 2012) menar att en viktig utgångspunkt i analysen av olika organisationers arbete med människor är förståelsen av deras representationer av olika problem och lösningar. När olika yrkesgrupper riktar sitt intresse mot enligt dem viktiga problemområden kartläggs problemen och dess orsaker samtidigt som arbetsmetoder och människor som betraktas som ett problem som problematiska - blir ett objekt för insatser. Genom problematisering styrs således arbetsmetoder och individers beteende mot av organisationerna utsatta mål, normer och förhållningssätt. Vilka problematiseringar är då de mest framträdande i diskurserna om samverkan?

\section{Transformation genom lärande i "Närområdets gemensamma styrka"}

Startpunkten för analysen är beskrivningar av de grundidéer och organisationsstrukturer som genomsyrar samverkansprocessen NGS. Analysen går sedan från den övergripande organisationsnivån till den operativa nivån, där aktiviteten "hemma-hos-kvällar" används som ett särskilt illustrativt exempel på problematiseringar av kommunikation, lärande, relationer, dialog, medborgerlig delaktighet, anpassning till det lokala och nya sätt att förstå demokratisk styrning och olika professionella yrkesroller.

NGS, som initierats av en frivilligorganisation, har beskrivits som en särskild framgångsrik insats som sedan starten för ett halvt decennium sedan har utvecklats till en öppen, nätverksbaserad och tvärsektoriell samverkan mellan ett femtiotal partnerorganisationer tillhörande offentligfinansierad sektor, näringslivet och frivilligorganisationer (privata och kommunala fastighetsägare, blåljusmyndigheter, skolrepresentanter, religiösa samfund, etnoreligiösa organisationer, kulturföreningar, stadsutvecklare, hjälp-, bistånds- och rättsorganisationer och så vidare). Själva samverkans namn, Närområdets gemensamma styrka, är mångbottnat 
såtillvida att det anspelar på vikten av att fokusera alla inblandade parters erfarenheter, kunskaper och styrkor mot gemensamma mål liksom kollegialt samarbete, erkännande av det lokala samhällets potential och deras betydelse för förändring. Mycket tyder på att det är tron på förändringsbehov och förändringspotential i Närområdet - liksom samverkansdeltagarnas eget inneboende engagemang och passion och syn att något radikalt och nytt måste göras för att en långsiktig och hållbar förändring ska ske - som driver fram samverkan och som gör att parterna sammansluts i samverkansnätverket.

Med resilienslogiken som följeslagare är det inte överraskande att förebyggande trygghets- och säkerhetsarbete har definierats som NGS:s viktigaste arbetsområde och en grundförutsättning för det goda livet i Närområdet (jfr Andersson \& Nilsson 2017). Vid sidan om detta anses kampen mot så kallad platsdiskriminering - det vill säga strävan efter att förändra de sätt "vi uttrycker oss om olika områden och att vi bemöter andras sätt att tala om områden" - vara ett särskilt prioriterat fokusområde (fältanteckningar 26 november 2015). Medan trygghets- och säkerhetsarbete liksom strategisk kommunikation intar en central plats i problematiseringarna, är man förhållandevis tyst om strukturella problem och orsaksförklaringar. Icke desto mindre har NGS ett mycket brett fokus och förståelse av problem, dess orsaker och lösningar. NGS består nämligen av sex huvudtemagrupper: kultur, utbildning och fritid, arbetsmarknad, sociala relationer och nätverk, trygghets- och säkerhetsfrågor och stadsutveckling. Utifrån sina egna erfarenheter, intressen och behov ansluter sig olika organisationer och dess representanter till de sex temagrupperna. Interaktionen och samverkan sker i varje enskild temagrupp under gemensamma informations- och planeringsmöten och/eller operativa möten där man diskuterar, planerar, koordinerar och utför en viss aktivitet. Dessutom koordineras hela NGS av en övergripande samordningsgrupp (se nedanstående diskussion om "ryggraden").

\section{Komplexa problem kräver långsiktighet}

NGS framhävs som ett förhållandevist informellt samarbete, grundat på nätverksbaserade kontakter och strukturer, där individuellt engagemang och lokala behov snarare än budgetramar och formella avtal är 
verksamhetens ryggrad och drivkraft (intervju med temasamordnaren Lo). I stället för en förutbestämd och centralutformad budget, ekonomisk detaljstyrning och från början fördelade roller och ansvarsområden understryks det att NGS behöver söka ekonomiskt stöd externt, finna sina egna vägar för samverkan och utforma gemensamma målbilder och framtidsvisioner. Ramverket är med andra ord inte helt givet och förutbestämt, förutom att samverkan i sig är en oemotsagd norm. I stället talas det om ständiga omvandlingar, anpassningar och dynamisk omstrukturering av hur samverkan ska organiseras och vad som bör stå i fokus. Tankegångarna är symptomatiska för resilienstänkande (jfr Chandler 20I4), inte minst då NGS:s deltagare betonar öppenhet, tillgänglighet, mångfald och horisontell organisation dit "vem som helst kan komma och vem som helst kan bjuda in" nya deltagare som vill arbeta för att förändra det särskilt utsatta området till en populär, säker och gemytlig stadsmiljö, där det är möjligt att "förverkliga sina livsval" (fältanteckningar 26 november 20I5, 5 december 20I4; kommunikationsmaterial 20I4, 2015, 2016). Utgångspunkten verkar vara att ju fler man är och ju fler röster som man får in i samverkansprocessen, desto bättre helhetsgrepp och genomslagskraft kan man få.

Den resiliensinspirerade tolkningshorisonten har även satt sin prägel på benämnandet av själva den samverkan som här studeras. För NGS:s samordnare och utvecklare har det varit ytterst viktigt att understryka att det hela är en "process" och ett "forum" och att NGS är en antites till tidigare projekt, som förknippas med "projekttrötthet" bland representanterna för lokalsamhället samt med enkelriktade, ovanifrån bestämda och beställda, kortsiktiga och "isolerade insatser" där endast en eller några få deltagarorganisationer med förutbestämda ansvarsområden ingår (fältanteckningar 26 november 20I5; intervju med temasamordnaren Lo; kommunikationsmaterial 20I5). Begreppet "process" tolkas i stället som "långsamt framåtskridande", något som anses vara en nödvändighet i en värld där det inte finns några "enkla och snabba lösningar" utan där problemen är "komplexa". Komplexitetsteorin är enligt Chandler (2014) en central del i resilienstänkande, särskilt eftersom den komplexa verkligheten och de komplexa problemen uppfattas som något positivt och kreativt och en startpunkt för förändringsarbete och ordningsskapande. 
Risker uppfattas inte som något enbart hotande, utan snarare som en del av livet eller ekosystemet, en förutsättning för det och möjlighet för förändring och utveckling.

Benämnandets symboliska värde får ytterligare dimensioner i själva namnet, Närområdets gemensamma styrka. För det första betyder namnet NGS ett samlande och en inkorporering av resurser (mänskliga och ekonomiska), inte minst genom inkludering och aktivering av representanter för lokalsamhället i gemensamt förändringsarbete och beslutsfattande. För det andra symboliserar namnet både en fokusering och koncentration av resurser och styrkor från en mångfald av olika parter, erfarenheter och synsätt. De båda aspekterna är besläktade såtillvida att de innefattar kollegialitet, ömsesidighet, gemensamt engagemang och målinriktat arbete, delat ansvar, synergi och oskiljaktighet, det vill säga några av resilienstänkandets centrala perspektiv (Chandler 20I4).

\section{Överbryggande av isolering ökar effektivitet och kräver gemensamma mål}

NGS initierades av en frivilligorganisation som självreflexivt hade dragit slutsatsen att deras och andra organisationers tidigare insatser och arbetssätt i Närområdet hade varit ineffektiva och hade misslyckats med att engagera lokalsamhället och att utgå från lokala förutsättningar och behov (fältanteckningar 26 november 20I5, II mars 20I5; intervju med temasamordnaren Lo). Enligt temasamordnaren Lo har organisationerna tidigare varken lyssnat på lokalsamhället eller haft en helhetsbild av området. Även de politiska krafterna ansvariga för hållbar urban utveckling poängterar vikten av att "gå ifrån stuprörstänkande" eftersom i "komplexa system" "hänger allting ihop" (skolan, sociala frågor, arbete, boende etcetera) - "delarna måste utgöra helheten", som man uttrycker det i sitt framhävande av mångfalden av olika parter (fältanteckningar 20 september 20I7). Kritiken har således riktats mot institutionalisering som lett till isolering, storskalighet och "stuprörsinriktade" arbetssätt och tankesätt (intervju med temasamordnaren Lo). Slutsatsen som hen drar är att lösningarna till de "komplexa" problem som finns i Närområdet kräver att man "bryter upp stuprören": 
Om man träffar en individ då ska man kunna se att "den här personen har problem med de här, de här och de här grejerna”. Plocka samman de här grejerna till en helhet så att det blir logiskt för [individen], i stället för att [hen] först ska prata med skolan och kuratorn om alla de grejer som händer där, sen ska den till socialen och prata om olika grejer där, sen om [hen] har gjort något dumt, ja då ska [hen] prata med polisen som skickar individen tillbaka till den där. Man bollar runt människor för mycket. Samhället är mer och mer komplext. (Intervju med temasamordnaren Lo.)

Kritiken av bristande flexibilitet, ineffektivitet, uppifrånstyrning, dikotomin mellan subjekt och objekt (organisationer och klienter) och okänslighet för verklighetens komplexitet och livsproblemen i sig känns igen från resilienstänkande. Detta betonar som vi har sett verklighetens och problemens oförutsägbarhet och komplexitet (Chandler 20I4). Likaså utgår resiliens från premissen att åtgärdsinsatserna bör ske genom skapandet av anpassningsbara, förändringsbenägna, utforskande och självreflexiva subjekt och organisationer som utgår från just verkligheten som källan till kunskap (Reid 20I6).

En av centralfigurerna i vetenskapliggörandet, evidensbaseringen och legitimeringen av NGS:s samverkansprocess, och tillika utbildaren och utforskaren av NGS (nedan kallad "Kim"), uppmärksammar just dissonansen mellan å ena sidan tidigare men enligt hen fortfarande dominerande instrumentella organisationsstrukturer och åtgärder och å andra sidan den komplexa verkligheten (se även kommunikationsmaterial 2015, 20I7; fältanteckningar 5 december 20I4, 26 november 20I5, I2 juni 20I7; intervju med temasamordnaren Lo). Hens poäng följer Jeremy Walker och Melinda Coopers (2OII) argumentation att resiliens som styrningsrationalitet försöker motverka samhälls- och organisationsstrukturers trögrörlighet, slutenhet, rigiditet, överbyråkratisering och icke mottaglighet för förändring och anpassning till det omgivande samhället och den komplexitet som anses råda i dagens samhälle. Kim, Lo och flera andra hävdar att dessa och liknande organisations- och styrningsproblem kan övervinnas genom gränsöverbryggande samverkan, organisationers och dess representanters anpassning till det lokala sammanhangets särdrag och aktivering av lokalsamhället. Enligt dem kräver samtida åtgärdsinsatser i utsatta urbana rum ett helt nytt sätt att tänka och agera. Självreflektion över tidigare misslyckanden, självkritik, problematisering, öppenhet, 
gränsöverbryggande och hybriditet har härmed inte bara blivit ett centralt inslag i synen på framgångsfaktorer, utan även ett sätt att legitimera och driva fram förändring på grundval av resiliens som styrningsrationalitet och organisationsmodell (jfr Chandler 20I4).

NGS:s initiativtagare har funnit teoretisk och organisatorisk inspiration i de resilienspräglade idéerna om en "kollektiv påverkansmodell" (engelska collective impact model, CIM; för beskrivning av modellen se Kania \& Kramer 20II). Det uttalade målet tycks vara att undanröja "tävlandet" och "konkurrensen" mellan olika organisationer och i stället "satsa på att samverka" och uppnå "synergi” i det lokala eftersom samverkan anses kunna skapa förutsättningar för framgång, ”ömsesidigt lärande" och innovation (fältanteckningar II mars 20I5, 26 november 2015). Motiveringen som anges är att "när människor träffas då uppstår nya idéer" och engagemanget och entusiasmen sprids vidare till andra människor (fältanteckningar II mars 20I5, 26 november 20I5). NGS tycks vila på premissen att "så länge vi ser att engagemanget växer", "vi har en magkänsla att förändring sker", vi kan "i realtid se vad man har lärt sig" och vi kan se "mervärde" på individnivå, organisationsnivå och i området - så behöver vi inte ha "rapporter" om effekter och söka externt erkännande (fältanteckningar I8 februari 20I8). NGS försöker gå ifrån en konkurrenslogik och i stället implementera en ny modell som framhäver samförstånd, synergi, ömsesidigt lärande och kollegialitet som framgångsfaktorer (jfr Coaffee 20I3). Genom att betrakta alla organisationer och medborgare som "medskapare" av förändring strävar man således efter ett holistiskt perspektiv, en utveckling av "viljan att se helheten" och integration, vilket inbegriper disciplinöverbryggande organisationsstrukturer, lösningar och tankesätt, som i sig är resilienstänkandets grundstenar (fältanteckningar 26 november 2015, I2 juni 20I7; kommunikationsmaterial 20I4).

Symptomatiskt för NGS är det uttalade målet att bli ett "forum" för att "stärka varandra" och "fogas samman" så att slutprodukten blir vad de kallar "we are one", där deltagarna "ser sig själva som ett system" (fältanteckningar 26 november 20I5; kommunikationsmaterial 20I6, 20I7). För att visualisera denna sammanfogningsprocess och samförståndspolitik använder forskaren och utbildaren Kim följande bild: 

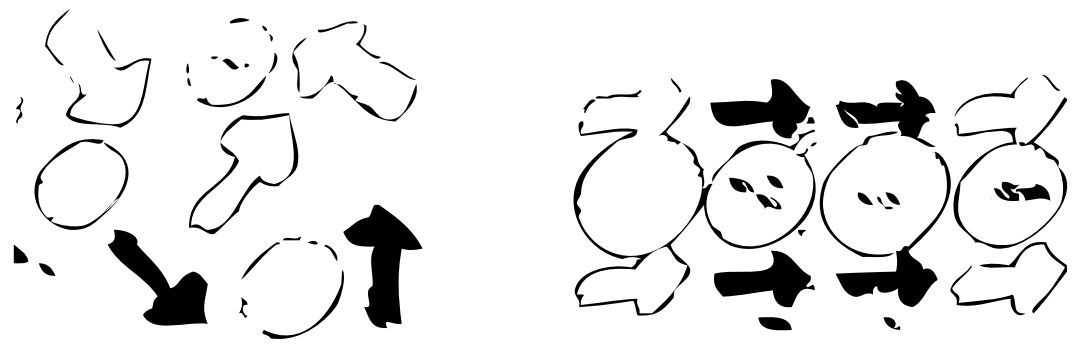

Bild I. Från tidigare desorientering och skilda riktningar till likriktning, samförstånd och gemensamma mål (med hänsyn till anonymiteten används inte originalbilden; fältanteckningar 26 november 20I5).

Bild I föreställer en förskjutning från okoordinerade och splittra(n)de insatser, där var och en arbetar för sig och på sitt eget sätt, mot samförstånd, samverkan, samordning, integration, lokalförankring och likriktning. Målet är med andra ord att "minska splittring" och skapa förutsättningar så att organisationerna "inte motverkar varandra" (fältanteckningar 5 december 20I4). En annan bild som används för att exemplifiera samverkans grundläggande drag och styrkor och som en symbol för "ömsesidigt förstärkande aktiviteter" är en illustration av ett träd som växter ur jorden eller ur det lokala:

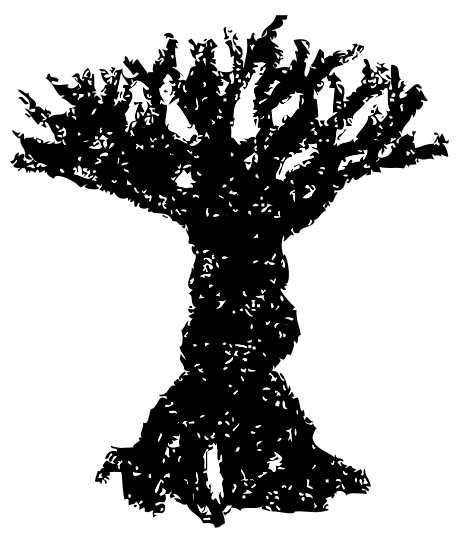

Bild 2. Vi växer samman och skapar en blomstrande framtid (med hänsyn till anonymiteten används inte originalbilden; fältanteckningar 26 november 20I5). 
Trädet i bild 2 föreställer i originalbilden fyra olika sammanflätade människokroppar: kropparna är olikfärgade, fötterna som föreställer rötter består av olika typer av skor (flip-flops, "manliga finskor", sportskor, och "kvinnliga" högklackade skor), stammen består av ben som är täckta av olika klädesplagg (det vill säga föreställer olika individer och professioner) och trädtoppen har nya skott och knoppar. Med hjälp av bilden som kommunikationsredskap lärs samverkansdeltagare att det är viktigt att foga samman skilda erfarenheter och grupperingar, skapa "kunskapsallianser” och få en mångfald av deltagare (de professionella yrkesutövarna och lokalsamhället) att växa ihop till en ömsesidigt beroende enhet i syfte att möjliggöra en ny utveckling och en blomstrande tillväxt eller framtid.

Grundantagandet som präglar de båda bilderna, liksom innehållet i interna diskussioner och extern kommunikation, är att helheten är större än summan av delarna - "Samhället är inte bara det offentliga, alla vi är samhället" (fältanteckningar 20 september 20I7). Jon Coafee och Jonathan Clarke (2015) och David Chandler (2014) har konstaterat att samtida problematiseringar grundade på resilienslogik framhäver just vikten av kollegialt samarbete, gemensamma mål, ömsesidig interaktion, lokalförankring och utsuddandet av gränser. Enligt forskarna ställs resiliens mot en liberal logik som understryker professionell specialisering, organisatoriskt särskiljande, kontroll och hierarkier.

\section{Samverkan kräver stödåtgärder}

Samverkan mellan olika parter och yrkesroller har en inneboende sårbarhet, menar Ingrid Sahlin (2000), och detta är något som NGS:s samordnare är väl medvetna om. Aktiva insatser med syfte att skapa en ny gemensam identitet, ömsesidighet, sammanflätning, beroende och en kollektiv vilja samt minska risker för misslyckande fordrar enligt samordnarna organiserad och målinriktad styrning. "Det sker inte av en slump att vi kan sammanfoga varandra", konstateras det (fältanteckningar 26 november 2015), och därför har man skapat samverkansprocessens "ryggrad" (engelska backbone support organisation). Kommunikations-, samordnings- och ledningsgrupp (tillsammans ryggraden) har som mål att få samverkansdeltagarna att utveckla gemensamma kompetenser 
och se "en gemensam nytta" (fältanteckningar I2 juni 20I7, 26 november 20I5; kommunikationsmaterial 2015, 20I7). I detta syfte används en mängd olika strategier, till exempel att "etablera och följa upp den gemensamma handlingsplanen”, skapa förutsättningar för gemensamt och ömsesidigt lärande, "bygga intern motivation och extern legitimitet", "mobilisera ekonomiska medel till sig själv och helheten" och sist men inte minst att leda arbetet med NGS:s "visionsstrategi" (fältanteckningar 26 november 20I5; kommunikationsmaterial 20I7; intervju med temasamordnaren Lo).

Helen Sullivan och Chris Skelcher (2002) samt Randi Gressgård (20I6) framhåller att strategisk kommunikation i allmänhet och visionsarbete i synnerhet används för att peka ut riktlinjer, stärka samverkansparters motivation, inge tro och hopp, frambringa känsla av kontroll och komma till bukt med destabiliserande effekter av skilda viljor, agendor och professionskulturer som finns när olika professioner och individer ska arbeta tillsammans. Resonemanget känns igen från Kims påpekande att i stället för att "scale up" (skala upp) behöver man "scale deep" (arbeta på djupet) - i stället för att fokusera på förändringar i övergripande lagar, policydokument och ekonomiska ramverk behöver man satsa på transformativt lärande så att de inblandade kan förstå och anpassa sig till den unika sociala och rumsliga kontexten, arbeta med lokala parter och på djupet förändra relationer, normer, kulturer och de människor som ingår i olika processer (kommunikationsmaterial 20I7; för begreppsdefinition se Moore m.fl. 20I5). Karakteristiskt för denna styrningsrationalitet är att "allt handlar om lärande", något som hänger samman med ett målinriktat arbete med att få samverkansdeltagare att utveckla ett "eget språk och egen kultur" och "stegvis lämna den egna agendan till förmån för den gemensamma (också ekonomiskt!)" (fältanteckningar 26 november 2015, 9 februari 20I8; kommunikationsmaterial 2016, 2017). Följaktligen efterfrågas en resiliensinspirerad förskjutning av tidigare fasta professionsidentiteter och kunskaper och särskiljandet av ekonomiskt ansvar till förmån för "kunskapsallianser", gemensamt ansvarstagande och mer flytande kostnadsfördelning (fältanteckningar 2I mars 20I6; jfr O’Malley \& Hutchinson 2007). Intressant nog uppfattas inte ryggradens strategiska kommunikation som en form av centralstyrning och kontroll. 


\section{Experimentella arbetssätt och anpassning till det lokala ger mervärde}

I NGS:s logik tolkas det lokala, vardagen, människors liv eller "verkstadsnivån" som ett "ekosystem" till vilket organisationer behöver anpassa sig men också som en lösning på tidigare misslyckanden (fältanteckningar 26 november 2015, 2I mars 2016; kommunikationsmaterial 20I7). Chandler (20I4, s. 65, min översättning) ser en tydlig koppling mellan det lokala/vardagen/livet/verkligheten å ena sidan och makt och resiliensbaserad styrningsrationalitet å den andra:

Resilienstänkande baseras på synen att makten ska utövas genom styrning av livet: genom aktivering, egenmakt [empowerment], möjliggörande och utveckling av individens inneboende kapacitet. Styrning kan inte ske över livet utan endast genom livet. Att styra "genom" snarare än "över" livet innebär införandet av en mycket mer platt ontologisk relation mellan de styrande och de styrda. Politiska mål, om de inte ska bli underminerade, måste komma från livet. Livet är mål och medel för styrning, där styrningen baseras på policyer som utformas utifrån lokala villkor och behov, självreflexivitet, återkopplingsslingor [feedbackloops] och införlivandet av lokalsamhällets kapacitet och resiliens.

Det empiriska materialet är rikt på diskurser om livets och verklighetens inneboende komplexitet och synen att det lokala snarare är en resurs, tillgång och förutsättning för styrning och ordningsskapande än ett hinder för utveckling och lösningar på problem - det gäller att fokusera på "tillgångar" snare än "utmaningar", som man uttrycker det (fältanteckningar 20 september 20I7).

Exempelvis, för att illustrera det lokalas/vardagens/verklighetens/ livets styrande inverkan i allmänhet och dess betydelse för organiseringen av samverkansprocessen i synnerhet använder forskaren och utbildaren Kim en bild (se bild 3) av tusentals svärmande fåglar. Kims metafor har omfamnats av NGS och svärmande fåglar används i dag som NGS:s officiella logga.

Fåglar som svärmar är ett kollektivt självorganiseringssystem där tusentals fåglar rör sig i en sammanhållen grupp, förändrar kollektivets utseende organiskt utifrån yttre faktorer och rör sig i en kollektiv formation utan en uppenbar ledning och ordning - det ser ut som om de kontrolleras av en osynlig hand (Hemelrijk \& Hildenbrandt 20II). När 


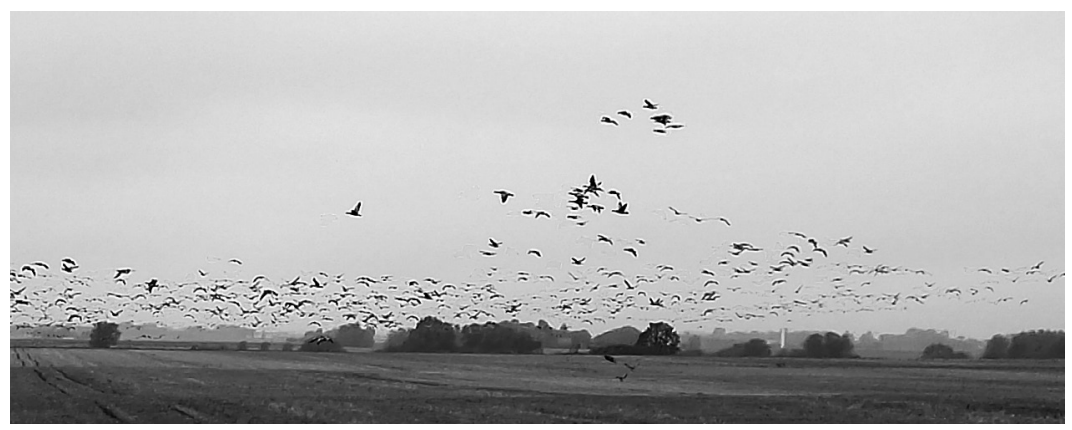

Bild 3. Svärmande fåglar i formation (detta är inte NGS:s originallogga utan bilden används som en illustration). Foto: Hanna-Beata Christensson 2017.

kollektivet blir anfallet eller när det möter ett hinder i miljön reorganiseras det och ändrar form, men utan att gemenskapen löses upp. Svärmande fåglar är med andra ord en hållbar och motståndskraftig (resilient) kollektiv självorganiseringsstruktur och ett exempel på organisk komplexitet, som innebär att resultaten, riktningen och utvecklingen inte är "kända, förutsägbara eller kontrollerbara" (Chandler 20I4, s. I7I, min översättning).

För det första är svärmande fåglar en illustrativ metafor och ett exempel på strategisk kommunikation varigenom man försöker få till stånd en samverkansprocess där "nätverk" av samverkansparter transformerar sig själva och de aktiviteter de organiserar "organiskt" (fältanteckningar 26 november 20I5, 2I mars 20I6). NGS "lever ett eget liv utifrån behoven”, så att säga. Målet tycks vara en adaptiv, hållbar, öppen, flexibel och experimenterande kultur vars maximer är: "hela NGS är ett test, vi vet inte hur det blir", "vi är fria att testa väldigt mycket och vi måste fortsätta testa" och när "vi möter problem anpassar vi oss till det" (fältanteckningar 2I mars 20I6; jfr Garland 2000a, 2000b). Sålunda betraktas verkligheten och det vardagliga eller lokala som startpunkter för organisationernas självreglering och ordningsskapande genom ständig anpassning till och lärande utifrån den komplexa verkligheten. I sin analys av resilienstänkandets genomslagskraft under det senaste decenniet 
konstaterar Chandler (20I4) att "verkligheten" och "livet i sig", tolkas som inneboende kvaliteter och krafter som möjliggör ordningskapande och som inspirationskälla för utformande och organisering av policypraktik och styrningsrationalitet. Resilienstänkande utgår sålunda från antagandet att det är möjligt att styra livet och skapa ordning genom att anpassa sig till hur livet spontant självorganiseras (Chandler 20I4). För det andra skildras både NGS och det specifika urbana rummet som ett unikt laboratorium för nya former av styrning eller som temasamordnaren Lo uttrycker det: "Det är rätt typiskt att man gör det i Närområdet, för att man vågar testa i Närområdet.” Det går att hävda att Närområdets position som ett särskilt utsatt och komplext område legitimerar nya, mer experimentella eller oprövade former av styrning som syftar till att katalysera framväxten av ett mer hållbart samhälle.

Sammantaget genomsyras diskurser om NGS av synen att lärande, experimentering och förändringsbenägenhet är en förutsättning för att göra Närområdet till en mer säker, trygg och positiv levnadsmiljö. Dessutom tolkas förhållnings- och arbetssätt med fokus på anpassning till det lokala och lokalsamhället som nya sätt att "demokratisera styrning" (fältanteckningar 2I mars 20I6). I det följande ska jag ytterligare belysa diskurser om demokratisering av styrning, relationsskapande kommunikation, lärande och anpassning till det lokala utifrån ett konkret och lokalförankrat exempel på brottsförebyggande arbete kallat "hemma-hos-kvällar".

\section{Demokratisering, aktivering och lärande genom relationer}

NGS:s idégrund baseras på premissen att "beteende hos individer måste man jobba med" och att man kan nå "framgångar genom relationer" (fältanteckningar 6 februari 20I5). En av de mest uppmärksammade aktiviteterna som vilar på dessa principer är hemma-hos-kvällar, som är ett resultat av samverkan mellan kommunrepresentanter och olika representanter för blåljusverksamheter (jfr Lozic 20ı6; Dahlstedt \& Lozic 20ı7b). Syftet är att nå "prioriterade, särskilt utsatta grupper" i det lokala, inte minst individer som man har "svårt att kommunicera med via befintliga informationskanaler". I detta sammanhang är kvinnor med "begränsad kontakt med det svenska samhället" och "som fastnat i integrations- 
processen” en särskilt angelägen målgrupp (kommunikationsmaterial 20I4, 20I5; intervju med trygghetssamordnaren Ellis). Genom att närma sig dessa särskilt utsatta individer vill man "förhindra att fler [ungdomar] hamnar i kriminella kretsar" eftersom dessa kvinnor är en viktig kanal för att nå "hela familjen". "Att förstå kvinnornas situation bättre är viktigt såväl för att upptäcka nya risker som för att kunna lämna anpassade och användbara svar och lösningar”, konstaterar hemma-hos-kvällarnas initiativtagare (kommunikationsmaterial 2015). Samtidigt som kvinnorna uppfattas som en riskfaktor representerar de också en viktig resurs i den lokala miljön (jfr Lozic 20I6; Dahlstedt \& Lozic 20ı7b).

Som mamma tänker jag hela tiden på att vara en god förebild. Att gå upp och jobba varje morgon, vara en del av samhället och stå på egna ben. (Kommunikationsmaterial 20I4.)

Interaktionen mellan kvinnorna och organisationsrepresentanterna är betydelsefull eftersom den skapar nödvändiga förutsättningar för att kvinnorna ska börja agera som positiva förebilder och ta ansvar för familjemedlemmarna. Därtill framhävs relationsskapandet som en viktig del i "den interna lärprocessen" och ett sätt att "bygga upp ett förtroende hos de boende", något som har beskrivits som ett allmänt problem i särskilt utsatta områden (kommunikationsmaterial 2015; Polisen 2015, 2017; Magnusson 20I4). Dessutom betraktas dessa utsatta individers "delaktighet" som en viktig förutsättning för att aktivera lokalsamhället så att det kan "påverka det som sker utanför den egna dörren, nere på gården eller vid mataffären”. Vad kännetecknar då hemma-hos-kvällarna?

Hemma-hos-kvällar äger rum flera gånger per halvår och vid varje möte anmäler sig en frivillig kvinna att vara "värdinna”. Värdinnan ansvarar för att "lägga upp programmet", ordna fika och bjuda in nya kvinnor från sitt eget sociala nätverk till "personliga och intima" umgängen i värdinnans eget hem (kommunikationsmaterial 2014, 2015). Intimitet, affektiva arbetssätt och småskalighet, som stimuleras med hjälp av bland annat "godis, frukt och kakor" och doften "av nybryggt kaffe [som] får gästerna att piggna till", anses vara viktiga medel för att få kvinnorna att känna "ägandeskap" och främja demokratisering av förändringsarbetet i allmänhet och trygghets- och säkerhetsarbetet i synnerhet (intervju med 
trygghetssamordnaren Ellis; kommunikationsmaterial 20I4). I empirin framställs även uniformen som distansskapande och "avskräckande" och för att få till stånd "intim stämning och samtal" samt "skapa relationer" har man implementerat ett arbetssätt man kallar "människan bakom uniformen" (fältanteckningar 2I mars 2016, 6 februari 20I5; intervju med trygghetssamordnaren Ellis). Detta grundas på närhets- och relationsbyggande och i detta syfte kommer blåljusverksamheternas representanter civilklädda till värdinnornas hem efter traditionella arbetstider.

Diskurserna om relationsskapande kommunikation genomsyras av synen att det är "mycket lättare att prata med varandra om man känner varandra" och om möten är "naturliga", ”äkta” och "spontana” (fältanteckningar 5 december 20I4, 2I mars 20I6). Med tanke på dessa grundidéer och mål är det inte överraskande att NGS:s gemensamma kommunikationsavdelning eller ryggrad beskriver mötena på följande sätt:

Den utsatta timmen för träffen har snabbt blivit två. Mitt i allvaret klingar skratten. Relationer har knutits och möten skapats. Ingen vill gå hem. En kvinna erbjuder sig att vara värdinna för nästa [hemma-hos-kväll]. Nästa datum bokas snabbt in. Ute regnar det fortfarande men inne finns en glöd som värmer länge. (Kommunikationsmaterial 20I4.)

Sensmoralen är att mötet har skapat nya subjektspositioner, produktiva personliga relationer och att de blivit en tändande gnista för medborgarnas delaktighet. En intensifiering av affektiva relationer mellan lokalsamhället och de inblandade organisationerna är en tydlig förskjutning mot resilienstänkande. Chandler (2014) menar att ett resultat av resilienstänkandets genomslagskraft är att det har skett ett skifte i relationer mellan statliga och andra organisationer å ena sidan och medborgare å den andra och som en konsekvens av detta har en omdefiniering av demokratibegreppet ägt rum.

Uppmaningar till mer demokrati innebär ofta att man fokuserar på samhällsmedborgarnas roll i stället för statens. Likaledes relateras demokrati till ett bemyndigande av människor och krav på ansvarstagande snarare än att göra statliga institutioner mer ansvariga inför medborgarna. [...] Kraven på utvidgning av demokratin till den sociala, privata och informella sfären särskiljer resilienstänkande från demokrati såsom den har definierats i förmodern och modern tid. (Chandler 20I4, s. I66, min översättning.) 
Utifrån det ovan diskuterade går det att dra slutsatsen att hemma-hoskvällarnas fokus på relationsskapande leder till att etablerade gränser mellan formell och informell, privat och offentlig, styrning och demokrati, socialisering och övertalning, kunnig och okunnig (expert och novis), professionella relationer och vänskap, och legal/laglydig och brottsli(n)g blir mer diffusa (Chandler 20I4; Lozic 20I6). Vidare tolkas demokrati som en fråga om närhet, vilket inbegriper antagandet att om problem och lösningar uppfattas som lokalt förankrade så engagerar sig lokalsamhället och den representativa demokratin stärks, inte minst när det gäller den utsatta befolkningen som ansetts vara oengagerad (fältanteckningar 20 september 20I7). Men Chandler (2OI4) varnar för att när demokrati tolkas som personliga relationer och informella och affektiva processer $\mathrm{i}$ det privata (till exempel när det sker i medborgarnas egna hem), då finns det en risk för försvagning av insyn i myndigheters arbetssätt och beslutsfattande processer. Även om den nyliberala diskursen traditionellt har varnat för myndigheters inblandning i den privata sfären, tycks denna problembild vara undanskymd i den studerade samverkansprocessen. I stället inramas samverkan, närhetsprinciper och relationsskapande i det privata i diskurser om "demokratikompensatoriskt arbete", det vill säga synen att det är frivilliga och engagerade subjekt som självständigt väljer att delta i samverkan för förändring (fältanteckningar 20 september 20I7). Ytterligare en viktig poäng som genomsyrar problematiseringarna är att intensifiering av relationer och involvering av många olika aktörer leder till att brottsförebyggande arbete inte blir bara en angelägen fråga för myndigheter, utan även för medborgare och frivilligorganisationer, som tillsammans och av sin fria vilja och utifrån ett eget engagemang aktivt deltar i förändringsarbetet, av sig själva, av lokalsamhället och av sina organisationer.

\section{Avslutande diskussion}

Det har skett ett skifte i problematiseringen av brottsförebyggande arbete, inte minst när det gäller de sätt man arbetar på för att lösa problem i så kallade särskilt utsatta områden (jfr Andersson \& Nilsson 20I7; Gressgård \& Lozic kommande). Artikelns centrala poäng är att 
de rådande problematiseringarna, som sätter sin prägel på den studerade samverkansprocessen Närområdets gemensamma styrka, eller NGS, genomsyras av resilienstänkande. Att resiliens har blivit ett begrepp och ett tankesystem som fått en stor genomslagskraft inom många olika områden har lyfts fram av många forskare, både i Sverige och internationellt (jfr Bergström m.fl. 20I5; Chandler 20I4; Corry 20I4). Det finns dock stora forskningsluckor när det gäller att synliggöra hur olika organisationsrepresentanter framställer och legitimerar samverkansbehov i allmänhet och resiliensinspirerat förebyggande trygghets- och säkerhetsarbete i synnerhet i en svensk lokal kontext.

I sin legitimering av förändring mot resilienstänkande understryker en central person för stadsutveckling: "Det finns inte någon messiassystemlösning på så komplexa system, i stället måste vi samverka, samskapa" (fältanteckningar 20 september 2017). Poängen är i viss mån motsägelsefull eftersom samverkan härigenom upphöjs till att bli en överordnad lösning och en norm som inte får eller kan ifrågasättas - kanske just för att inom ramen för resilienstänkande uppfattas samverkan som en naturlig och essentiell del av livet och hållbar samhällsutveckling.

I diskurserna om behovet av ett skifte i sättet att tänka och agera framhävs en kritik av tidigare arbetssätt, som anklagas för kortsiktighet och ineffektivitet och för att vara reduktionistiska och frånkopplade från den komplexa verkligheten och lokalsamhället. I stället för en ovanifrån bestämd organisatorisk fragmentering och ett stuprörstänkande efterfrågas resiliensinspirerade problematiseringar, som betonar synergi, symbios, helhetstänkande, integration, gränsöverskridande, ömsesidigt och transformativt lärande, affektiva arbetsmetoder, förändringsbenägenhet och att stärka egenmakten hos och bemyndiga lokalsamhället (jfr Chandler 20I4; O’Malley 20I3). Paradoxalt nog, trots kritiken av tidigare arbetssätts bristande helhetsperspektiv, innebär växande fokus på det lokala, verklighetsnära och relationsbyggande att man även tystar ned strukturella orsaksförklaringar (Andersson \& Nilsson 20I7; Lozic 20I6; Dahlstedt \& Lozic 2017a, 2017b). Trots att svärmande fåglar används som den studerade samverkansprocessens logga så har inte ett fågelperspektiv (ovanifrån, ett brett helhetsperspektiv) fått en dominerande position. I stället har det lokala, det nära och livet i sig (mikronivån) blivit 
mål och medel för styrning. Med tanke på resilienstänkandets genomslagskraft är det inte heller överraskande att trygghets- och säkerhetsfrågor och brottsprevention har beskrivits som allt viktigare lösningar på ett brett spektrum av sociala och andra problem i det studerade särskilt utsatta området (jfr Andersson \& Nilsson 2017).

Viktigt är att understryka att alla dessa värden, kompetenser och metaforer (till exempel holism, affektivitet, lokalförankring, svärmande fåglar och så vidare) även synliggör de sätt man ser på medborgarideal och eftersträvansvärda subjektskap. I diskurserna framhävs exempelvis kravet på inre engagemang och ömsesidig aktivering av både lokalsamhället och de professionella yrkesutövarna samt av olika yrkesutövare sinsemellan. Alla inblandades personliga och professionella utveckling och lärande förväntas ske kollegialt och utifrån gemensamma mål, samtidigt som gränsen mellan de olika subjekten och deras roll har ifrågasatts och utmanats. Till följd av kollegialitetens ökade betydelse tycks den personliga och yrkesmässiga autonomin och självständigheten ha marginaliserats. Därutöver förväntas de inblandade samverkansdeltagarna utveckla en förmåga att se den komplexa verkligheten och de oförutsägbara och eskalerande problemen i det särskilt utsatta området som något produktivt och positivt - en källa till ny kunskap, kontinuerligt lärande och fortsatt omprövande av beslut och handlingar utifrån livet och den lokala verkligheten som empiri (jfr Chandler 20I4). Kontroll och stabilitet som troligtvis fanns, i alla fall på ett teoretiskt och diskursivt plan, när stuprörstänkande och professionell gränsdragning var dominerande tankesystem, tycks ha gett vika för en komplexitetsteori, för obeständighet och experimentella och innovativa arbetssätt.

Avslutningsvis har det i spåren av mer platta, nätverksbaserade och affektiva relationer mellan lokalsamhällets representanter och organisationer växt fram en ny tolkning av demokrati, där demokrati tolkas som uppluckring av traditionella gränser mellan privat och offentligt, professionellt och relationellt (privat eller personligt), affekt och effekt, yrkesutövare och klient och så vidare. Demokratifostran innebär att man arbetar aktivt med att stärka särskilt utsatta subjekts förmåga att uttrycka sina röster, ge sin bild av verkligheten och ta över ägandeskapet över sina egna liv och lokalsamhället (jfr Dahlstedt 2009). Samtidigt som man 
arbetar aktivt med att etablera affektiva relationer och närma sig lokalsamhället och dess privata sfär, ifrågasätter man inte uppluckringen av gränsen mellan privat och offentligt och av klientskyddet som en demokratisk rättighet. Detta är en central faktor som särskiljer resilienstänkande från problematiseringar som har som sin huvudkritik i just statens och tjänstemäns maktutövning över och involvering i den privata sfären (jfr Sahlin 2000).

\section{Referenser}

Andersson, Robert \& Nilsson, Roddy (2017) Svensk kriminalpolitik. Stockholm: Liber. Andersson, Robin (2017) Samverkan i demokratins forrsvar. En studie om den offentliga sektorn, civilsambället och arbetet mot våldsbejakande extremism. Göteborg: Göteborgs universitet.

Arnstberg, Karl-Olov (2000) Miljonprogrammet. Stockholm: Carlsson.

Bacchi, Carol L. (2010) Foucault, policy and rule. Challenging the probem-solving paradigm. Aalborg: Aalborg Universitet.

Bacchi, Carol L. (2012) "Why study problematizations? Making politics visible", Open Journal of Political Science, 2, I, s. I-8. DOI: https://doi.org/IO.4236/ojps.20I2.2100I

Bergström, Johan, van Winsen, Roel \& Henriqson, Eder (2015) "On the rationale of resilience in the domain of safety: A literature review", Reliability Engineering \& System Safety, I4I, s. I3I-I4I. DOI: https://doi.org/I0.10I6/j.ress.2015.03.008

BRÅ (2016) Samverkan. I lokalt brottsförebyggande arbete. Stockholm: Brottsförebyggande rådet.

BRÅ (2017) Nationella trygghetsundersökningen 2016. Om utsatthet, otrygghet och förtroende. Stockholm: Brottsförebyggande rådet.

Chandler, David (2014) Resilience. The governance of complexity. Abingdon: Routledge.

Coaffee, Jon (2010) "Protecting vulnerable cities: The UK's resilience response to defending everyday urban infrastructure", International Affairs, 86, 4, s. 939-954. DoI: https://doi.org/IO.IIII/j.I468-2346.20I0.00921.x

Coaffee, Jon (2013) "Rescaling and responsibilising the politics of urban resilience: From national security to local place-making", Politics, 33, 4, s. 240-252. DOI: https://doi.org/IO.IIII/I467-9256.I2OII

Coaffee, Jon \& Clarke, Jonathan (2015) "On securing the generational challenge of urban resilience", Town Planning Review, 86, 3, s. 249-255. DOI: https://doi.org/I0.3828/tpr.20I5.I6

Corry, Olaf (2014) "From defense to resilience: Environmental security beyond neoliberalism", International Political Sociology, 8, 3, s. 256-274. DOI: https://doi.org/IO.IIII/ips.I2057 
Dahlstedt, Magnus (2009) Aktiveringens politik. Demokrati och medborgarskap för ett nytt millenium. Malmö: Liber.

Dahlstedt, Magnus \& Hertzberg, Fredrik (20II) Skola i samverkan. Miljonprogrammet och visionen om den öppna skolan. Malmö: Gleerup.

Dahlstedt, Magnus \& Lozic, Vanja (2017a) "Managing urban unrest: problematising juvenile delinquency in multi-ethnic Sweden", Critical and Radical Social Work, 5, 2, s. 207-222. DoI: https://doi.org/IO.I332/2049860I7XI4933953111175

Dahlstedt, Magnus \& Lozic, Vanja (20I7b) "Problematizing parents: Representations of multi-ethnic areas, youth and urban unrest", i Ålund, Aleksandra, Schierup, CarlUlrik \& Neergaard, Anders (red.) Reimagineering the nation. Essays on twenty-firstcentury Sweden. Frankfurt am Main: Peter Lang.

de los Reyes, Paulina m.fl. (20I4) "Bilen brinner ... men problemen är kvar". Berättelser om om Husbyhändelserna i maj 20I3. Stockholm: Stockholmia förlag.

Edvall Malm, Disa (2012) Det socio-polisiära handlingsnätet. Om kopplingar mellan polis och socialtjänst kring ungdomars kriminalitet och missbruk. Umeå: Umeå universitet.

Ekberg, Margareta S. (20IO) Dom kallar oss värstingar. Om ungas lärande i mötet med skola, socialtjänst och polis. Växjö: Linnaeus University Press.

Garland, David (2000a) "Ideas, institutions and situational crime prevention", i von Hirsch, Andrew, Garland, David \& Wakefield, Alison (red.) Ethical and social perspectives on situational crime prevention. Oxford: Hart Publishing.

Garland, David (200ob) "The new criminologies of everyday life: Routine activity theory in historical and social context", i von Hirsch, Andrew, Garland, David \& Wakefield, Alison (red.) Ethical and social perspectives on situational crime prevention. Oxford: Hart Publishing.

Gressgård, Randi (2016) "Welfare policing and the safety-security nexus in urban governance", Nordic Journal of Migration Research, 6, I, s. 9-I7. DOI: https://doi.org/10.I515/njmr-2016-0003

Gressgård, Randi \& Lozic, Vanja (kommande) "Strategic communication of the 'shift' from security to resilience in urban security politics: Shifting temporalities and shifting status of failure”, Theory \& Society, inlämnad artikel, under sakkunniggranskning.

Hallin, Per Olof, Jashari, Alban, Listerborn, Carina \& Popoola, Margareta (2010) Det är inte stenarna som gör ont. Röster frän Herrgården, Rosengård - om konflikter och erkännande. Malmö: Malmö högskola.

Hemelrijk, Charlotte K. \& Hildenbrandt, Hanno (20II) "Some causes of the variable shape of flocks of birds", Plos One, 6, 8, e22479.

DOI: https://doi.org/IO.I37I/journal.pone.0022479

Hertting, Nils (2003) Samverkan på spel. Rationalitet och frustration i nätverksstyrning och svensk stadsdelsförnyelse. Stockholm: Égalité.

Kania, John \& Kramer, Mark (2OII) "Collective impact", Stanford Social Innovation Review, vinter, s. 36-4I.

URL: https://ssir.org/articles/entry/collective_impact (I2 april 20I8) 
Lozic, Vanja (20I6) "Normalisering av ungdomar i problem genom styrning av föräldrar: Från strukturella orsaksförklaringar till familjecentrerade lösningar”, Sociologisk Forskning, 53, 2, s. I5I-I74.

Magnusson, Susanna (20I4) Att säkerställa att vi är välkomna. Om organisationers strategiska kommunikation och förtroendeskapande arbete $i$ det mångkulturella samhället. Lund: Lunds universitet.

Mayer, Margit (2016) "Neoliberal urbanism and uprising across Europe", i Mayer, Margit, Thörn, Catharina \& Thörn, Håkan (red.) Urban uprisings. Challenging neoliberal urbanism in Europe. London: Palgrave Macmillan.

Molina, Irene (1997) Stadens rasifiering. Etnisk boendesegregation i folkhemmet. Uppsala: Uppsala universitet.

Moore, Michele-Lee, Riddell, Darcy \& Vocisano, Dana (2015) "Scaling out, scaling up, scaling deep: Strategies of non-profits in advancing systemic social innovation", The Journal of Corporate Citizenship, 58, s. 67-84. Dor: https://doi.org/10.9774/GLEAF.4700.2015.ju.00009

MSB (2013) Bättre samverkan i ett nätverkssamhälle - Governing for societal resilience. Karlstad: Myndigheten för samhällsskydd och beredskap.

MSB (2016a) Local resilience against radicalization. How cooperation between civil society and local public actors can be strengthened and improve crisis preparedness. Karlstad: Myndigheten för samhällsskydd och beredskap.

MSB (20I6b) Samhällelig resiliens: Ett begrepps genomslag, utveckling och användning - $i$ Sverige och internationellt. Karlstad: Myndigheten för samhällsskydd och beredskap.

O’Malley, Pat (2013) "Uncertain governance and resilient subjects in the risk society", Oñati Socio-Legal Series, 3, 2, s. 180-195. URL: http://opo.iisj.net/index.php/osls/article/view/I83 (I2 april 20I8)

O’Malley, Pat \& Hutchinson, Steven (2007) "Reinventing prevention: Why did 'crime prevention' develop so late?", The British Journal of Criminology, 47, 3, s. 373-389. DOI: https://doi.org/IO.IO93/bjc/azlo92

Polisen (20I5) Sociala risker och kollektiv förmåga. Stockholm: Polismyndigheten.

Polisen (20I7) Utsatta områden. Social ordning, kriminell struktur och utmaningar för polisen. Stockholm: Nationella operativa avdelningen.

Ranstorp, Magnus (2015) Förebyggande av våldsbejakande extremism på lokal nivå. Stockholm: Försvarshögskolan.

Reid, Julian (2016) "Adaptation: The war on authonomy", i Chandler, David \& Reid, Julian (red.) The neoliberal subject. Resilience, adaptation and vulnerability. London: Rawman \& Littlefield.

Ristilammi, Per-Markku (1999) Rosengård och den svarta poesin. En studie i modern annorlundahet. Stockholm: Symposion.

Rose, Nikolas S. (1999) Powers of freedom. Reframing political thought. Cambridge: Cambridge University Press.

Rose, Nikolas S., O’Malley, Pat \& Valverde, Mariana (2006) "Governmentality", Annual Review of Law and Social Science, 2, I, s. 83-IO4.

DoI: https://doi.org/I0.II46/annurev.lawsocsci.2.081805.I05900 
Rädda Barnen (2015) Barnfattigdom i Sverige. Årsrapport 20I5. Stockholm: Rädda Barnen.

Sahlin, Ingrid (2000) Brottsprevention som begrepp och samhällsfenomen. Lund: Arkiv.

Schierup, Carl-Ulrik, Ålund, Aleksandra \& Kings, Lisa (20I4) "Reading the Stockholm riots - a moment for social justice?", Race \& Class, 55, 3, s. I-2I.

DoI: https://doi.org/I0.II77/030639681350919I

Sullivan, Helen \& Skelcher, Chris (2002) Working across boundaries. Collaboration in public services. Houndmills: Palgrave.

Söderberg, Christina (20I6) Individriktad brottsprevention. Om SSPF och viljan att samverka. Linköping: Linköping University Press.

Thörn, Håkan, Mayer, Margit \& Thörn, Catharina (2016) "Re-thinking urban social movements, 'riots' and uprising: An introduction", i Mayer, Margit, Thörn, Catharina \& Thörn, Håkan (red.) Urban uprisings. Challenging neoliberal urbanism in Europe. London: Palgrave Macmillan.

Vale, Lawrence J. (20I4) "The politics of resilient cities: whose resilience and whose city?", Building Research \& Information, 42, 2, s. I9I-20I. DoI: https://doi.org/Io.I080/096I32I8.2014.850602

Wacquant, Loïc (2008) Urban outcasts. A comparative sociology of advanced marginality. Cambridge: Polity Press.

Walker, Jeremy \& Cooper, Melinda (20II) "Genealogies of resilience: From systems ecology to the political economy of crisis adaptation", Security Dialogue, 42, 2, s. $143-160$.

DoI: https://doi.org/Io.II77/09670I06113996I6 


\section{INGRID SAHLIN}

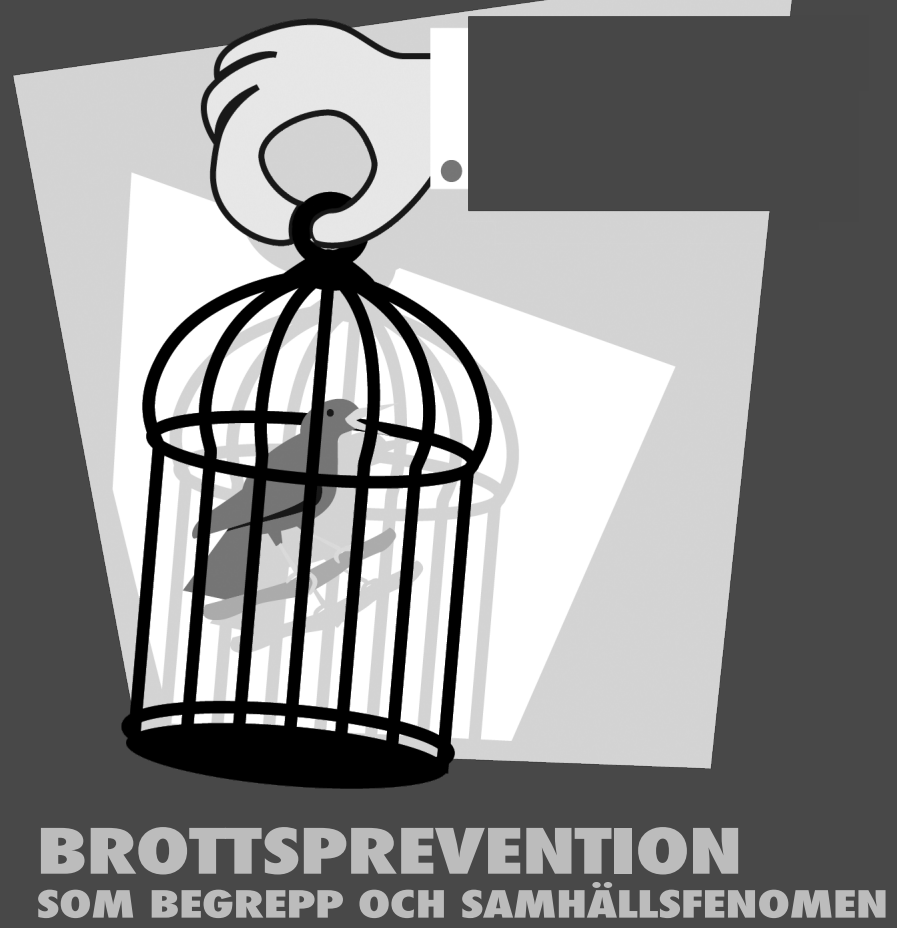

I BROTISPREVENION SOM BECREPP OCH SAMHALLSFENOMEN diskuterar Ingrid Sahlin brottspreventionens historiska rötter och uttryck, liksom den människosyn och samhällsvision som dagens brottsprevention bygger på. Hon hävdar att valet av preventionsmodell är politiskt och att det påverkar vår syn på brottslighetens orsaker. Slutsatsen är att brottspreventionen bör betraktas och studeras som en del av samhällets ideologiproduktion, snarare än som rationella åtgärder för ałt mołverka kriminalitet.

ARKIV FÖRLAG, 178 SIDOR 